\title{
Detection of Apoptosis in Paraffin Embedded Tissues: the Influence of Tissue Type and Fixation
}

\author{
L. DUBSKÁ ${ }^{1,2}$, E. MATALOVÁ ${ }^{3}$, I. MÍŠEK $^{3}$
}

${ }^{1}$ Department of Genetics and Molecular Biology, Masaryk University, Brno, ${ }^{2}$ Laboratory of Apoptosis Research, Masaryk Memorial Cancer Institute, Brno, ${ }^{3}$ Institute of Animal Physiology and Genetics, Academy of Sciences, Brno, Czech Republic

Received May 21, 2001

Accepted November 18, 2002

Abstract

Dubská L., E. Matalová, I. Míšek: Detection of Apoptosis in Paraffin Embedded Tissues: the Influence of Tissue Type and Fixation. Acta Vet Brno 2002, 71: 529-533.

With increasing importance of apoptosis, many assays have been developed to detect apoptosis in cell populations and individual cells. Apoptotic cells are often proved using TUNEL assay based on detection of DNA strand breaks that occur during apoptosis. The method enables quantification of apoptotic cells by flow cytometry, fluorescence as well as by light microscopy when modifications using marker enzymes are applied. Disadvantages of this method are false positive and negative findings.

In this study, the influence of different methods of fixation on TUNEL POD results was investigated. Three commonly employed fixative procedures using formaldehyde, methacarn and Bouin's fluid were applied. Two bovine tissue types of different cell density (thymus and ovary) were used to test this effect. Different pretreatments were tested for an influence upon false negative findings. Results were evaluated under light microscopy and photographed.

We observed that, in the absence of a universal molecular marker of programmed cell death, it is essential for reliable apoptosis detection to optimize the chosen method for a given tissue and fixation. It is also strongly recommended to employ at least two methods, measuring different features of the apoptotic process to obtain reproducible results in detection of apoptosis.

TUNEL assay, paraffin embedded tissues, thymus, ovary

Apoptosis is a cell-suicide mechanism that plays a crucial role in development and homeostasis of metazoans (J a c obs on et al. 1997). In spite of the fact that programmed cell death is currently one of the hottest areas of modern biology, reliable apoptosis evaluation in routine histological sections remains problematic.

Apoptosis recognition is still commonly based on morphological criteria (Kerr et al. 1972), such as cell shrinkage, blebbing, specific chromatin condensation and loss of cell-cell contacts. The ultrastructural features of apoptosis are relatively easily recognized. A complicating factor is relatively low frequency in which apoptotic cells are observed, especially in lieu of the rapid phagocytosis of these cells in vivo (B ar 1996; Ren et Savill 1998; Holmgren et al. 1999). Associated with the nuclear condensation, the biochemical hallmark of apoptosis is an extensive cleavage of the nuclear DNA into oligonucleosome-sized fragments. These fragments can be visualized as the typical ladder pattern using gel electrophoresis (A aij et Borst 1972) and DNA breaks can be detected in situ using enzymatic labeling system (Gavrieli et al. 1992). In the absence of a universal molecular marker of programmed cell death, these structural DNA alterations provide the basis for detection systems.

TUNEL (terminal deoxynucleotidyl transferase-mediated dUTP nick end-labeling) is an often chosen method for rapid identification and quantification of apoptosis in single cells and tissue sections. Two modifications of this assay detecting apoptosis in individual cells by light microscopy have been developed: TUNEL POD and TUNEL AP using peroxidase

Address for correspondence:

Mgr. Lenka Dubská

Laboratory of Apoptosis Research

Žlutý kopec 7, 65653 Brno, Czech Republic
Phone: +420 543136730

Fax:+420543211 169

http://www.vfu.cz/acta-vet/actavet.htm 
and alkaline phosphatase, respectively, as marker enzymes. In this article, we report on detection of apoptotic DNA breaks in two mammalian tissues (thymus and ovary) using commercially available TUNEL POD test (TdT-mediated dUTP nick end labeling). Advantages and disadvantages of different fixation procedures of this apoptosis detection method are demonstrated and discussed.

\section{Materials and Methods}

Tissue preparation

Two different bovine tissues - thymus and ovary were obtained from cattle at the abattoir. The tissues were collected immediately after killing and placed on ice for $30 \mathrm{~min}$ until fixation.

Fixation

Three different and commonly used types of fixation were tested. 1) 4\% [v/v] formaldehyde in water, $\mathrm{pH} 7.4$ (B ancroft et Cook 1994); 2) methacarn (methanol-Carnoy) (Romeis 1989): 10\% [v/v] acetic acid, 30\% [v/v] chloroform, in methanol, $\mathrm{pH}$ 5.0; 3) Bouin's fluid (B ancroft et Cook 1994): 4\% [w/v] picric acid in 3.5\% [v/v] formaldehyde, $1.5 \%[\mathrm{v} / \mathrm{v}]$ acetic acid in distelled water, $\mathrm{pH} 3.8$. Tissue fragments measuring $0.5 \mathrm{~cm}^{3}$ approximately were kept in the fixatives for about $20 \mathrm{~h}$ at room temperature.

Paraffin embedded tissue sections

After paraffin processing $3 \mu \mathrm{m}$ and $4 \mu \mathrm{m}$, respectively, thick tissue sections were prepared using microtome SM 2000R (Leica, Germany) and mounted on poly-L-lysine-coated glass slides. The samples were deparaffinized and rehydrated through a graded series of ethanol and distilled water.

Pretreatments - cell permeabilisation

In case of negativity in positive control samples three types of pretreatment were applied prior to enzymatic labeling. 1) proteolytic digestion: proteinase K (Sigma-Aldrich, Germany) $\left(20 \mu \mathrm{g} / \mathrm{ml}\right.$ in PBS)/ $15 \mathrm{~min} / 37^{\circ} \mathrm{C} /$ humidified chamber; 2) microwave irradiation (MW) in $0.1 \%$ sodium citrate solution/ $5 \mathrm{~min} / 400 \mathrm{~W}$; 3 ) detergent permeabilisation: $0.1 \%$ TRITON ${ }^{\circledR} \mathrm{X}-100$ in $0.1 \%$ sodium citrate/ $2 \mathrm{~min} / 0{ }^{\circ} \mathrm{C} ; 4$ ) proteolytic digestion after MW; 5) detergent permeabilisation after proteinase $K$ treatment.

TUNEL POD assay - labeling

Terminal deoxynucleotidyl transferase-mediated dUTP nick end labeling (In Situ Cell Death Detection Kit, POD) was used for proving apoptosis in individual cells. The TUNEL working procedure was carried out following the producer's directions (Roche, Germany). Endogenous peroxidase was blocked by incubation in $1.3 \% \mathrm{H}_{2} \mathrm{O}_{2}$ in PBS/ $10 \mathrm{~min} / \mathrm{RT}$ before enzymatic labeling. During the TUNEL procedure samples were washed in PBS: phosphate-buffer saline ( $\mathrm{pH} 7.4$ ): $137 \mathrm{mM} \mathrm{NaCl}, 2.7 \mathrm{mM} \mathrm{KCl}, 1.5 \mathrm{mM} \mathrm{KH}_{2} \mathrm{PO}_{4}, 8.1 \mathrm{mM} \mathrm{Na}_{2} \mathrm{HPO}_{4}$ in distilled water. The fluorescent signal conversion using anti-fluorescence antibody conjugated with peroxidase and substrate color reaction applying chromogen DAB (3,3'-diaminobenzidine tetrahydrochloride; Sigma-Aldrich, Germany) were proceeded after enzymatic labeling.

TUNEL POD assay - controls

Positive control of TUNEL POD labeling was prepared using DNase (Sigma-Aldrich, Germany) treatment. After pretreatment, histological sections were incubated with DNase $(5 \mu \mathrm{g} / \mathrm{ml})$ at $37^{\circ} \mathrm{C} /$ humidified chamber/ 10 min to induce DNA strand breaks.

Negative control was obtained by omitting terminal transferase from the labeling procedure (label solution only instead of TUNEL reaction mixture).

TUNEL POD assay - analysis

Counterstaining with alcian blue was performed before final analysis of apoptotic nuclei/bodies. Samples were photographed at a magnification of $400 \times$ using Coolpix camera (Nicon, Japan) after dehydration and mounting in EUKITT.

Cell morphology

For histological analysis tissue sections were stained using hematoxilin-eosin procedure and observed by oil immersion using light microscopy at a magnification of $1000 \times$ to evaluate morphological changes characteristic of apoptosis.

\section{Results}

Possible exploitation of TUNEL POD assay for proving apoptosis in situ with regards to false positive and negative findings was tested in this study. Positive control was achieved by 
exogenous DNase application; negative control was without labeling enzyme (terminal deoxynucleotidyl transferase). The fixation procedure ( $4 \%$ formaldehyde, methacarn, Bouin's fluid), the type of tissue (thymus and ovary) and the way of pretreatment were evaluated in respect of TUNEL-positive signal and morphology of cell and tissue. Results of TUNEL POD labeling were compared and documented (Plate XVII and XVIII, Figs. 1-6).

Type of tissue

In ovary, which represents the type of tissue with low cell density, the TUNEL-positive cells were scattered throughout in the $4 \mu \mathrm{m}$ sections after proteinase K pretreatment (Figs. $1,3,5)$. The highest rate of reaction-positive thymocytes was obtained in $3 \mu \mathrm{m}$ samples pretreated by exposure to MW irradiation followed by proteolytic digestion (Fig. 4).

\section{Fixation}

No significant difference in false positive or false negative TUNEL POD labeling results was demonstrated after short term fixation procedure in mentioned three types of fixative solution. Tissues fixed in methacarn were more sensitive to $\mathrm{pH}$ of the $\mathrm{DAB}$ reaction. The false positive findings were avoided when the color reaction was performed in $\mathrm{pH}=7.4$ solution (Figs. 2b, 5b). The morphology of cells and tissues was worse in samples fixed in Bouin's fluid, especially in ovary (Fig. 3). Regarding the histology together with appropriate TUNEL labeling, the best results were achieved in ovary and thymus samples after formaldehyde fixation (Fig. 1, 4).

\section{Pretreatment}

Detergent pretreatment or its combination with proteinase $\mathrm{K}$ was not efficient in improving permeability of cell, uniformly throughout the section. As noted above, proteolytic digestion provided low accessibility in thymic tissue (highest cell density). Only thymocytes at the margin of the lobules ("pseudolobules") were TUNEL-positive. MW irradiation ( $5 \mathrm{~min} / 400$ W) was sufficient for adequate TUNEL POD labeling throughout thymic sample. No increase in signal intensity and amount of TUNEL-positive cells were demonstrated in ovary sections when specimens were MW irradiated before proteinase K digestion. In addition, morphology of samples pretreated by this way was artifactually altered.

\section{TUNEL POD assay}

Different concentrations of DNase were tested $(5,50$, and $500 \mu \mathrm{g} / \mathrm{ml})$ for positive controls with the best results when using $5 \mu \mathrm{g} / \mathrm{ml}$.

Strong nonspecific background was present when the blocking of endogenous peroxidase activity was omitted. However, application of higher peroxide concentration (e.g. higher than $1.3 \%$ ) had no discernable benefit for reducing false positives.

Throughout our experiments, performing the TUNEL reaction under parafilm resulted in decreased levels of labeling in the center of the sections. This uneven labeling was eliminated and drying was avoided when specimens were incubated, without parafilm, in a humidified chamber.

\section{Discussion}

The aim of this study was to observe the influence of tissue type and its fixation on recognition of cells with DNA fragmentation after TUNEL POD labeling in histological sections. Effect of TUNEL POD assay in two thymic and ovarian tissues under three commonly used fixatives was investigated under light microscopy at a magnification of $\times 400$. False positive and negative findings were evaluated, along with morphology of tissue, background staining and recognition of apoptotic cells were the criteria employed. 
The TUNEL technique is widely used to demonstrate apoptosis in individual cells. This method enables enzymatic labeling and detection of genomic DNA breaks and thus quantification of apoptotic cells by FACS, fluorescence or light microscopy. However, the TUNEL assay is prone to false positive and negative results. Extensive TUNEL-positive signals can be explained by nonapoptotic DNA fragmentation, which occurs in numerous biological events, including: necrosis (Ohno et al. 1998); RNA synthesis and splicing (Kockx et al. 1998); DNA repair (Eastman and Barry 1992). Nonspecific enzymatic DNA disruption and labeling might be induced by sample fixation and paraffin-embedding (Ansari et al.1993; Negoescu et al. 1998); sectioning (Sloop et al. 1999); postmortem proteolysis (Wijsman et al. 1993); the staining kinetics and the reagent concentration (Migheli et al. 1994). A goal of this experimental study was to improve the accessibility of all cells within the tissue and while avoiding the nonspecific staining.

No significant influence of fixation on the accessibility of the tissues for the TUNELstaining was noted. Our results demonstrated that short-term fixation in $4 \%$ formaldehyde is suitable for application of TUNEL method. In addition to the disadvantages of Bouin's fluid and methacarn, there is also their inadequacy for long-term fixation with respect to the histologic structures of the tissue. We recommend formaldehyde fixation for TUNEL POD labeling of tissues with low cell density (ovary) where no false positive or negative findings were detected. The susceptibility to DNA breaks for enzymatic labeling is reduced by the nuclear protein environment (Kerrigan et al. 1987) and impaired by cell fixation (Gold et al. 1994). Therefore, chemical pretreatments of the biological samples have been devised to improve TUNEL sensitivity (Negoescu et al. 1997). Nevertheless, in this study the TUNEL sensitivity was dependent mainly on the type of tissue and the adequate pretreatment. In the absence of proteolytic digestion, nuclear labeling was faint in both thymus and ovary. False negative findings especially in the high-cell-density sections were avoided by adding a procedural step of MW irradiation. Detergent permeabilisation was found inefficient in the enhancing accessibility of the cells in tissues. Even the most intensive positive signal was lost when the DNase at low concentration was applied. High concentration of the enzyme probably results in extensive DNA cleavage, which alters incorporation of the labeled deoxynucleotides.

According to our results, the effect of enzymatic labeling using TUNEL POD test is tissue and fixation type dependent. Combining other methods with TUNEL, such as microscopic evaluation of morphological changes or assessment of the apoptotic DNA fragmentation pattern can substantiate the specificity of results. To obtain reproducible results, it is highly recommended to standardize the TUNEL test using positive control of apoptosis as well as of the labeling procedure and to evaluate enough microscopic fields. It is also essential to optimize the pretreatment process, the color reaction and the counterstaining for specific fixation and also tissue type, whereas TUNEL method can be applied without an extensive modification.

\section{Detekce apoptózy v parafínovaných tkáních: závislost výsledků na typu tkáně a fixaci}

Se vzrůstajícím významem programované buněčné smrti se zvyšuje množství metod umožňujících detekci apoptózy v buněčných populacích stejně jako v jednotlivých buňkách. Apoptotické buňky bývají často prokazovány pomocí TUNEL testu, založeného na detekci zlomů DNA, které se objevují během apoptózy. Tato metoda umožňuje kvantitativní analýzu apoptotických buněk pomocí průtokové cytometrie, fluorescenční a světelné mikroskopie. Výhody a nevýhody této metody jsou především falešně pozitivní a falešně negativní nálezy.

V této studii byl sledován vliv typu fixace na výsledky získané metodou TUNEL POD. Dva typy hovězí tkáně s různou hustotou buněk (brzlík, vaječník) byly fixovány třemi 
v histologii běžně používanými fixačními postupy: $4 \%$ formaldehyd, metacarn nebo Bouinův roztok. Různá předpůsobení byla testována $\mathrm{v}$ př́padech falešně negativních výsledků. Výsledky byly hodnoceny pomocí světelné mikroskopie a dokumentovány.

Pozorovali jsme, že pro spolehlivost detekce apoptotických buněk je nezbytná optimalizace zvolené metody na konkrétní typ tkáně a použitý postup fixace. Doporučována je rovněž kombinace alespoň dvou metod založených na rozdílných kritériích apoptotického procesu.

\section{Acknowledgements}

This work was supported by Ministry of Education of the Czech Republic by the Grant FRVS 731/2002 and partly supported by Grant Agency of the Czech Republic (grant 204/02/P112).

\section{References}

AAIJ C, BORST P 1972: The gel electrophoresis of DNA. Biochim Biophys Acta 269: 192-200

ANSARI B., COATES PJ., GREENSTEIN B. D., HALL, P. A. 1993: In situ end-labeling detects DNA strand breaks in apoptosis and other physiological states. J Pathol 170: 1-8

BANCROFT JD, COOK HC1994: Manual of Histological Techniques and their Diagnostic Application. Churchill Livingstone, UK, $457 \mathrm{p}$.

BAR PR 1996: Apoptosis-the cell’s silent exit. Life Sci 59: 369-78

EASTMAN A, BARRY MA 1992: The origins of DNA breaks: a consequence of DNA damage, DNA repair or apoptosis. Cancer Invest 10: 229-240

GAVRIELI Y, SHERMAN Y, BEN SASSON SA 1992: Identification of programmed cell death in situ via specific labeling of nuclear DNA fragmentation. J Cell Biol 119: 493-501

GOLD R, SCHMIED M, GIEGERICH G, BREITSCHOPF H, HARTUNG HP, TOKYTA K V, LASSMANN H 1994: Differentiation between cellular apoptosis and necrosis by combined use of in situ tailing and nick translation techniques. Lab Invest 71: 219-225

HOLMGREN L, SZELES A, RAJNAVOLGYI E, FOLKMAN J, KLEIN G, ERNBERG I, FALK KI 1999: Horizontal transfer of DNA by the uptake of apoptotic bodies. Blood 93: 3956-3963

JACOBSON MD, WEIL M, RAFF MC 1997: Programmed cell death in animal development. Cell 88: 347-354

KERR JFR, WYLLIE AH, CURRIE AR 1972: Apoptosis: a basic biological phenomenon with wide-ranging implication in tissue kinetics. Brit J Cancer 68: 239-257

KERRIGAN D, POMMIER Z, KOHN KW 1987: Protein-linked DNA strand breaks produced by etoposide and teniposide in mouse L 1210 and human VA-13 and HT-29 cell lines: Relationship to cytotoxicity. NCI Monogr 4: $117-121$

KOCKX MM, MUHRING J, HARMON BV 1998: RNA synthesis and splicing interferes with DNA in situ end labeling techniques used to detect apoptosis. Am J Pathol 152: 885-888

MIGHELI A, CAVALLA P, MARINO S, SCHIFFER D 1994: A study of apoptosis in normal and pathological nervous-tissue after in-situ end-labeling of DNA strand breaks. J Neuropath Exp Neur 53: 606-616

NEGOESCU A, GUILLERMET CH, LORIMIER PH, ROBERT C, LANTUEJOUL S, BRAMBILLA E, LABAT-MOLEUR F 1998: TUNEL: Apoptotic cell detection in archived paraffin-embedded tissues. Biochimica 3: 36-47

NEGOESCU A, LORIMIER P, LABAT-MOLEUR F, AZOTI L, ROBERT C, GUILLERMET C, BRAMBILLA C, BRAMBILLA E 1997: TUNEL: Improvement and evaluation of the method for in situ apoptotic cell identification. Biochimica 2: 12-17

OHNO M, TAKEMURA G, OHNO A, MISAO J, HAYKAWA Y, MINATOGUCIS, FUJIWARA T, FUJIWARA

H 1998: "Apoptotic" myocytes in infarct area in rabbit hearts may be oncotic myocytes with DNA fragmentation: analysis by immunogold electron microscopy combined with in situ nick labeling. Circulation 98: $1422-1430$

REN Y, SAVILL J 1998: Apoptosis: the importance of being eaten. Cell Death Diff 5:563-568

ROMEIS B 1989: Mikroskopische Technik. Urban und Schwanzenberg, Wien, 696 p.

SLOOP GD, ROA JC, DELGADO AG, BALART JT, HINES MO, HILL JM 1999: Histological sectioning procedures TUNEL reactivity: A potential cause of false-positive staining. Arch Pathol Lab Med 123: 529-532

WIJSMAN JH, JONKER RR, KEIJZER R, VAN DEN VELDE CJH, CORNELISSE CJ, VAN DIERENDONCK JH 1993: A new method to detect apoptosis in paraffin sections: In situ end-labeling of fragmented DNA. J Histochem Cytochem 41: 7-12 
Plate XVII

Dubská L. et al.: Detection ... pp. 529-533
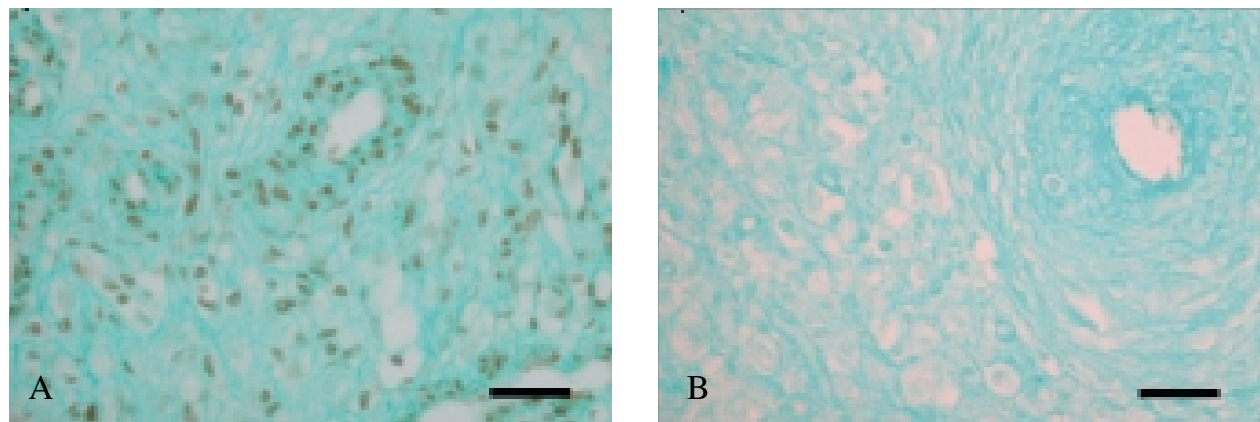

Fig. 1. TUNEL POD labeling of formaldehyde-fixed paraffin-embedded tissue of bovine ovary. Pretreatment: proteinase $\mathrm{K}\left(20 \mu \mathrm{g} / \mathrm{ml}, 15 \mathrm{~min}, 37^{\circ} \mathrm{C}\right)$. (A) Positive control: DNase $\left(5 \mu \mathrm{g} / \mathrm{ml}, 15 \mathrm{~min}, 37{ }^{\circ} \mathrm{C}\right)$. (B) Negative control: Counterstaining: alcian blue. $4 \mu \mathrm{m}$ sections. Original magnification: $\times 400$. Bar indicates $100 \mu \mathrm{m}$.
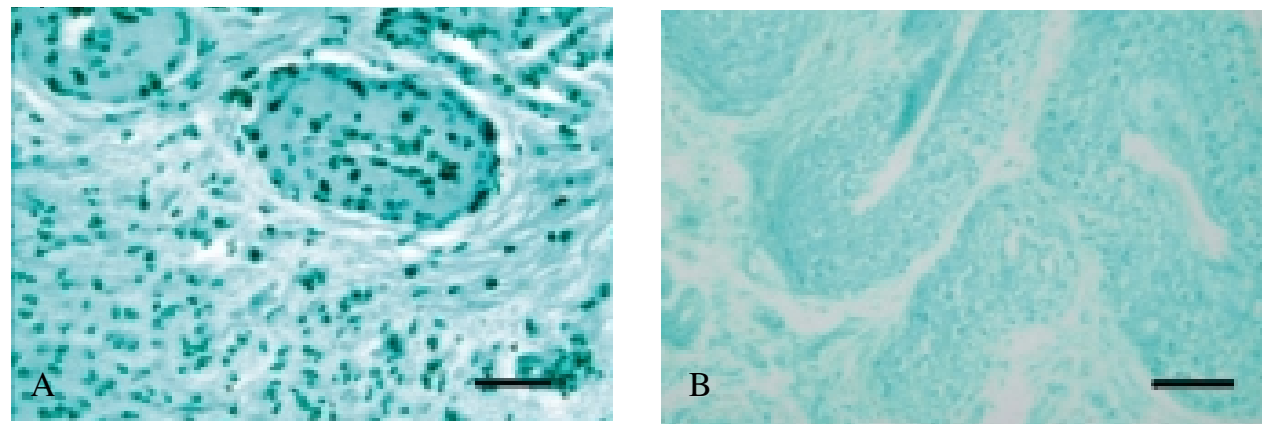

Fig. 2. TUNEL POD labeling of methacarn-fixed paraffin-embedded tissue of bovine ovary. Pretreatment: proteinase K $\left(20 \mu \mathrm{g} / \mathrm{ml}, 15 \mathrm{~min}, 37^{\circ} \mathrm{C}\right)$. (A) Positive control: DNase $\left(5 \mu \mathrm{g} / \mathrm{ml}, 15 \mathrm{~min}, 37^{\circ} \mathrm{C}\right)$. (B) Negative control: Counterstaining: alcian blue. $4 \mu \mathrm{m}$ sections. Original magnification: $\times 400$. Bar indicates $100 \mu \mathrm{m}$.
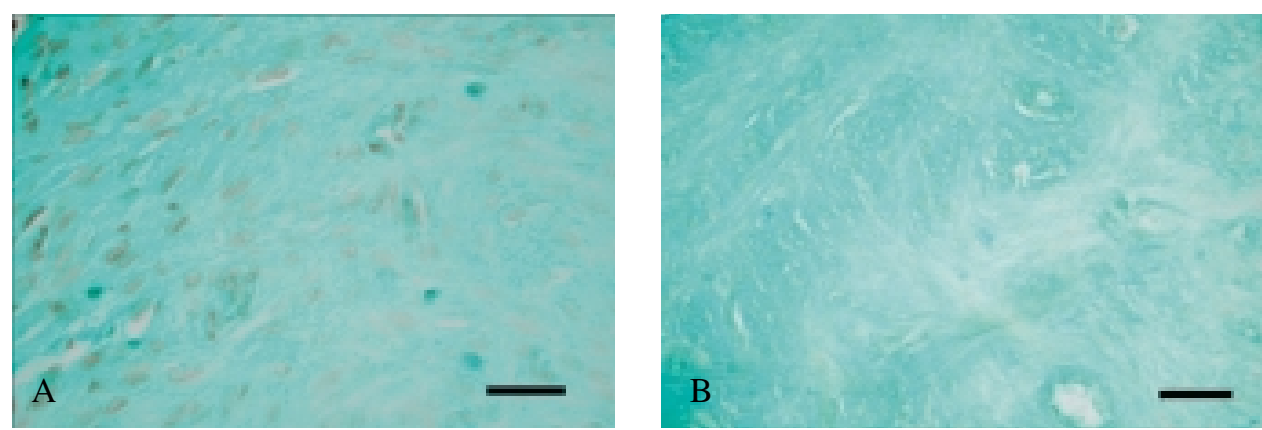

Fig. 3. TUNEL POD labeling of Bouin's fluid-fixed paraffin-embedded tissue of bovine ovary. Pretreatment: proteinase K $\left(20 \mu \mathrm{g} / \mathrm{ml}, 15 \mathrm{~min}, 37^{\circ} \mathrm{C}\right)$. (A) Positive control: DNase $\left(5 \mu \mathrm{g} / \mathrm{ml}, 15 \mathrm{~min}, 37^{\circ} \mathrm{C}\right)$. (B) Negative control: Counterstaining: alcian blue. $4 \mu \mathrm{m}$ sections. Original magnification: $\times 400$. Bar indicates $100 \mu \mathrm{m}$. 
Plate XVIII
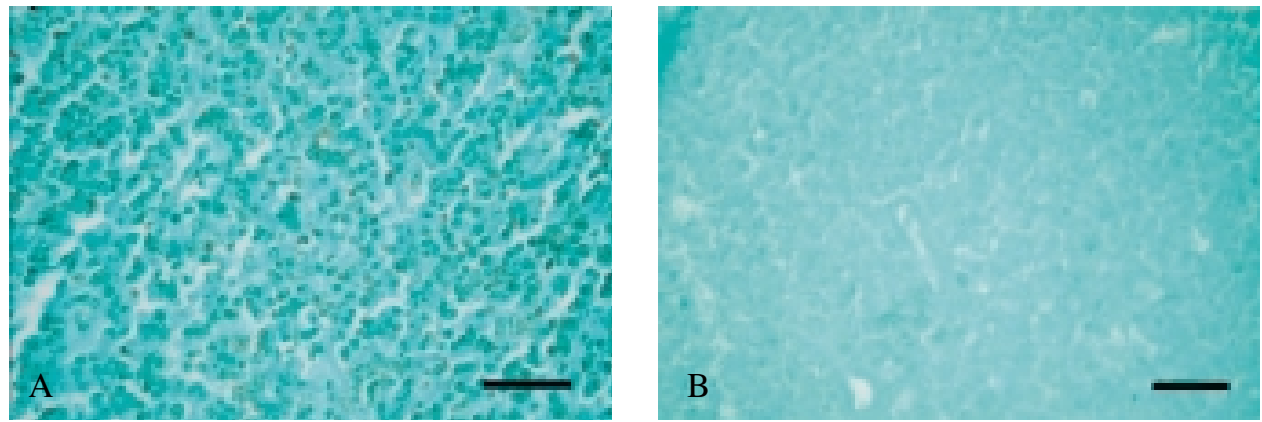

Fig. 4. TUNEL POD labeling of formaldehyde-fixed paraffin-embedded tissue of bovine fetal thymus. Pretreatment: proteinase $\mathrm{K}\left(20 \mu \mathrm{g} / \mathrm{ml}, 15 \mathrm{~min}, 37^{\circ} \mathrm{C}\right)$; MW (400 W, $\left.5 \mathrm{~min}\right)$. (A) Positive control: DNase ( $5 \mu \mathrm{g} / \mathrm{ml}$, $15 \mathrm{~min}, 37^{\circ} \mathrm{C}$ ). (B) Negative control: Counterstaining: alcian blue. $4 \mu \mathrm{m}$ sections. Original magnification: $\times 400$. Bar indicates $100 \mu \mathrm{m}$.
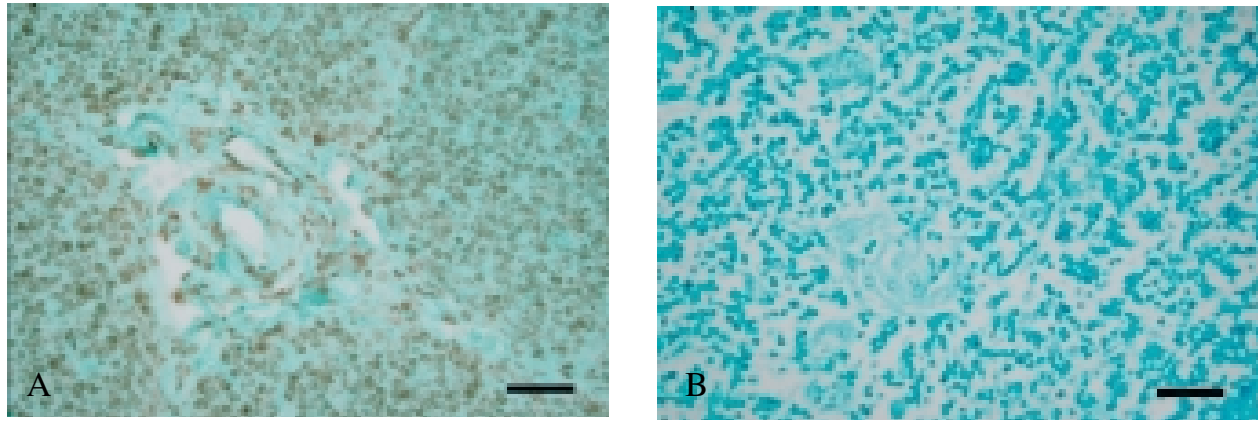

Fig. 5. TUNEL POD labeling of methacarn-fixed paraffin-embedded tissue of bovine fetal thymus. Pretreatment: proteinase K $\left(20 \mu \mathrm{g} / \mathrm{ml}, 15 \mathrm{~min}, 37^{\circ} \mathrm{C}\right)$; MW (400 W, $\left.5 \mathrm{~min}\right)$. (A) Positive control: DNase $(5 \mu \mathrm{g} / \mathrm{ml}, 15 \mathrm{~min}$, $37{ }^{\circ} \mathrm{C}$ ). (B) Negative control: Counterstaining: alcian blue. $3 \mu \mathrm{m}$ sections. Original magnification: $\times 400$. Bar indicates $100 \mu \mathrm{m}$.
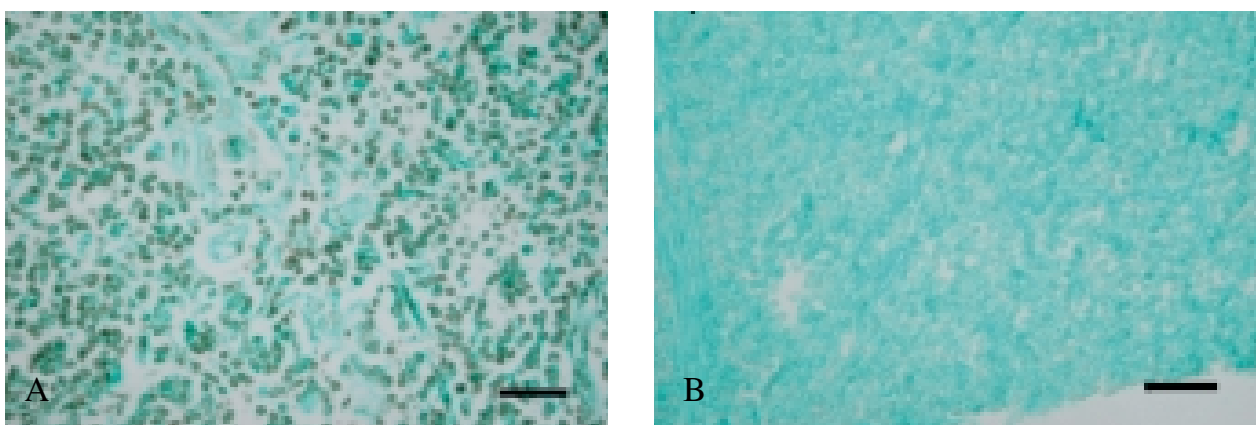

Fig. 6. TUNEL POD labeling of Bouin's fluid-fixed paraffin-embedded tissue of bovine fetal thymus. Pretreatment: proteinase $\mathrm{K}\left(20 \mu \mathrm{g} / \mathrm{ml}, 15 \mathrm{~min}, 37^{\circ} \mathrm{C}\right)$; MW (400 W, $\left.5 \mathrm{~min}\right)$. (A) Positive control: DNase $(5 \mu \mathrm{g} / \mathrm{ml}$, $15 \mathrm{~min}, 37^{\circ} \mathrm{C}$ ). (B) Negative control: Counterstaining: alcian blue. $3 \mu \mathrm{m}$ sections. Original magnification: $\times 400$. Bar indicates $100 \mu \mathrm{m}$. 